\title{
Investigation of the Effect of Decitabine on Hep-2 Cell Line at Chromosomal Level
}

\author{
Murat Kaya (Corresponding author) \\ Department of Medical Genetics of Internal Diseases, Istanbul Medical Faculty, Istanbul University, \\ Capa Campus 34844, Fatih Istanbul, Turkey \\ E-mail: kmurat@istanbul.edu.tr \\ Ilknur Suer \\ Department of Medical Genetics of Internal Diseases, Istanbul Medical Faculty, Istanbul University, \\ Capa Campus 34844, Fatih Istanbul, Turkey \\ E-mail: ilknursuer@gmail.com
}

\begin{abstract}
DNA methylation is an epigenetic event that is defined as the binding of a methyl group via DNA methyl transferases (DNMTs) to the fifth carbon of cytosine in the $\mathrm{CpG}$ dinucleotide. Regulation of the expressions of tissue-specific genes, regulation of gene expressions during development, $\mathrm{X}$ inactivation and imprinting events are caused by DNA methylation. The aberrant DNA methylation associated with various diseases, especially cancers, is one of the most studied epigenetic mechanisms. Decitabine, a nucleoside analogue, inhibits DNMT enzymes and causes hypomethylation in the genome. There are many studies investigating the aberrant DNA methylation status in the genome of cells treated with Decitabine. Karyotype analysis is a cytogenetic method, which has been used successfully for the detection of both numerical and structural chromosomal abnormalities for many years. Hep- 2 is a laryngeal cancer cell line, which is, used to investigate various genetic and epigenetic changes at the molecular level that revealed important information about the initiation and development of laryngeal cancer. However, the number of studies showing the chromosomal structure of Hep-2 cells is insufficient. The effects of Decitabine on cell morphology in different cell lines, its relationship with proliferation of the cells and its effects on chromosomes have been studied. However, the number of studies showing the effect of Decitabine at the chromosomal level in Hep-2 cell lines is also very limited. In current study, we investigated the chromosomes of Hep- 2 cells cultured 72 hours with $1 \mu \mathrm{M}$ and $10 \mu \mathrm{M}$ Decitabine and without Decitabine.
\end{abstract}

Keywords: Cell lines, Hep-2 cell line, Karyotyping, Decitabine, DNA methylation

DOI: $10.7176 / \mathrm{JSTR} / 5-4-11$

\section{Desitabinin Hep-2 Hücre Hattı Üzerindeki Etkisinin Kromozomal Düzeyde Araştırılması}

\begin{abstract}
Özet
DNA metilasyonu CpG dinükleotidindeki sitozinin beşinci karbonuna DNA metil transferazlar (DNMT) aracılığıyla bir metil grubunun bağlanmasını ifade eden epigenetik olaydır. Dokuya özgü genlerin ifadelerinin düzenlenmesi, gelişim süresince genlerin ifadelerinin düzenlenmesi, X inaktivasyonu ve imprinting olayları DNA metilasyon mekanizması sayesinde gerçekleşmektedir. Başta kanserler olmak üzere çok sayıda hastalıkla ilişkilendirilen aberran DNA metilasyonu üzerinde en çok çalışılan epigenetik mekanizmalardan birisidir. Bir nükleozit analoğu olan Desitabin, DNMT enzimlerini inhibe ederek genomda hipometilasyona neden olmaktadır. Hücre hatlarına desitabin uygulanarak genomdaki aberran DNA metilasyon durumunun araştırıldığı birçok çalışma mevcuttur. Karyotip analizi uzun yıllardır gerek sayısal gerekse belli büyüklükteki yapısal kromozom anomalilerinin tespitinde başarılı bir şekilde
\end{abstract}

98 | $P$ a g e

www.iiste.org 
kullanılan sitogenetik yöntemdir. Hep-2 hücre hattı larenks kanserine ait hücre hattıdır. Bu hücre hattı kullanılarak çeşitli genetik ve epigenetik değişikliklerin moleküler düzeyde araştırılması yapılmış ve larenks kanserinin oluşum ve gelişimi ile ilgili önemli bilgiler elde edilmiştir. Buna rağmen Hep-2 hücrelerinin kromozom yapısının gösterildiği çalışma sayısı çok yetersizdir. Desitabinin farklı hücre hatlarında hücre morfolojisine olan etkisi, proliferasyon ile ilişkisi ve kromozomlar üzerindeki etkisini gösteren çeşitli çalışmalar yapılmıştır. Ancak Desitabinin Hep-2 hücre hatlarında kromozomal düzeyde etkisini gösteren çalışma sayısı da yine son derece sınırlıdır. Bu çalışmada Desitabin eklenmeyen Hep-2 hücre kromozomları ile $1 \mu \mathrm{M}$ ve $10 \mu \mathrm{M}$ dozlarda desitabin eklenerek 72 saat kültüre edilen Hep-2 hücre hattı kromozomları yapısal ve sayısal olarak analiz edilerek sonuçlar karşılaştırılmıştır.

Anahtar Kelimeler: Hücre hattı, Hep-2 hücre hatt1, Karyotip analizi, Desitabin, DNA metilasyonu

\section{Giriș}

\subsection{Hücre Hatları}

Hücre hatları ilk olarak 1951 yılında agresif adenokarsinom servikal kanser sebebiyle takip edilen ve aslen Afrika kökenli olan Henrietta Lacks isimli hastanın kanser dokuları kullanılarak, Dr. George Otto Gey'in Johns Hopkins (Baltimore, Maryland) 'teki laboratuvarında elde edilmiştir. Bu yüzden elde edilen hücre hattı Henrietta Lack'a ithafen HeLa olarak isimlendirilmiştir (Lucey ve ark, 2009). Hücre hatları gerek araştırma gerekse ilaç geliştirme amacıyla in vitro model olarak elde edildikleri tarihten günümüze kadar sıklıkla kullanılmış̧ır. Çeşitli yollarla elde edilen hücre hatları uygun koşullar altında sınırsız bölünme yeteneğine sahiptir (ölümsüz). Hücre hatları ile ilgili yapılan çalışmalar; hücre büyümesi, gelişimi ve ölümüyle ilgili çeşitli biyolojik olayların aydınlatılması konularında yapılan çalışmaların temelini oluşturmaktadır. Bu durumun kanıtı olarak hücre hatlarıyla yapılan on binlerce yayının varlığ 1 gösterilebilir.

Hücrelerin ölümsüz hale gelmesi, hücrelere ait çeşitli biyolojik süreçlerde yapıllan bazı önemli değişikliklerle olur. $\mathrm{Bu}$ önemli değişiklikler; hücre bölünmesinin kontrolünde kilit rolü oynayan p53/p16/pRb yolaklarının bozulması, telomeraz aktivitesinin artırılması, bazı onkogenlerin upregüle edilmesi gibi değikliklerdir. Burada belirtilen hücre bölünmesini artırıcı etkenlerin devreye girmesiyle birlikte hücreler ölümsüz hale getirilmektedir (Maqsood ve ark, 2013). Hücre hatları kullanmanın birçok avantajı söz konusudur; mali açıdan büyük bir külfet oluşturmaması, çalışma kolaylı̆̆ı sağlaması, hayvan ve insan dokuları çalışılırken istenen ve ciddi prosedürleri olan etik kurul aşamasına gerek duyulmaması, çalışmayı yapan bilim insanlarına sınırsız bölünen hücreleri armağan ederek sınırsız materyal kaynak oluşturması gibi avantajlar örnek olarak verilebilir. Hücre hatları aşı üretim çalışmalarında, ilaç metabolizması sitotoksisitesi araştırmalarında, antikor üretiminde, genlerin fonsiyonlarının araştırılmasında, yapay doku üretim çalışmalarında ve çeşitli biyolojik bileşik üretim çalışmalarında tüm dünyada sıklıkla kullanılmaktadır (Kaur ve ark, 2012). Bizim de çalışmamızda kullandığımımız Hep-2 hücre hattının temin edildiği American Type Culture Collection (ATCC)'de 150 den fazla türe ait yaklaşık 4000 kadar hücre hattı bulunmaktadır (www.atcc.org).

\subsection{5-Aza-2'-deoksisitidin (Desitabin)}

Desitabin bir sitidin anoloğudur. Sitidinin pirimidin halkasındaki 5. karbon atomonun (C) yerine azot atomunun $(\mathrm{N})$ yerleşmesi sonucunda Desitabin molekülü oluşur. Desitabin en yaygın olarak kullanılan hipometilasyon ajanıdır. 1960'lı yılların başlarında sentezlenen bu madde sentezlendiği günden bugüne kadar pek çok çalışmada kullanılmıştır ve bu maddenin mutajenik, immünsüpresif, anti mitotik ve anti neoplastik özelliklerinin olduğu gösterilmiştir. Yüksek dozlar ile yapılan ilk çalışmalarda bu maddenin nükleik asit metabolizmasında görevli enzimler dahil pek çok enzimin aktivitesini etkilediği, hatta DNA, RNA ve protein sentezini inhibe ettiği gösterilmiştir (Christman ve ark, 2002).

Hipometilasyon ajanı olan Desitabin hücre içerisine alındığında o hücredeki metilasyonu kaldırmaz ancak o hücreye ait DNA'dan oluşan yeni DNA'daki metilasyon durumunu değiştirir. Yani Desitabin, bir hücrenin bölünerek oluşturduğu iki hücrede hemi metile şekilde etkiye sahiptir. Bu nedenle Desitabin maddesinin hücrelerdeki etkisini anlamak için ilaç hücrelere verildikten sonra hücrelerin en az iki hücre döngüsü geçirmesi gerekir (Hagemann ve ark, 2011).

Yapılan çok sayıdaki çalışmalar Desitabin maddesinin çok düşük dozlarda bile DNA'da hipometilasyona neden olduğunu göstermiştir. Nanomolar dozlar ve mikromolar dozlar ile yapılan çalışmalarda doz seviyesindeki artışa bağlı olarak DNA'daki hipometilasyon seviyesinde de artışın olduğunu göstermiştir 
(Hagemann ve ark, 2011). Yüksek doz Desitabine maruziyette DNA'nın yapısı bozulur ve hücre ölümü gerçekleşir (Stresemann ve ark, 2008). Desitabin maddesi genel olarak metil transferaz enzimlerini inhibe ederek ekspresyon seviyesinin artışına neden olmaktadır. Ancak Desitabinin bazı genlerin ekspresyon seviyesini azalttığına yönelik çeşitli çalışmalar da mevcuttur. Örneğin ilaç direnci ile ilgili yapılan çalışmada Desitabin eklenen insan eritro lösemi hücre hattı olan K562'de kontrol grubuna göre MDR-1 (Multi Drug Resistance-1) ekspresyonunun ifade düzeyinin azaldığı gözlenmiştir (Ando ve Ark, 2000). DNA metilasyonundaki değişikliklerin kromozomal değişikliklere yol açabildiğine dair yapılan çeşitli çalışmalar vardır (Lee ve ark, 2015). Desitabinin hipometilasyon yoluyla kromozomal değişimlere yol açabileceği bildirilmiştir (Harrison ve ark, 1983). Biz de bu çalışmamızda Hep-2 hücrelerine uyguladığımız Desitabinin kromozom düzeyinde değişiklik oluşturup oluşturmadığını araştırdık.

\section{Metod}

\subsection{Desitabininin Hep-2 Hücrelerine Eklenmesi}

Çalışmada kullanılan Hep-2 hücre hattı ATCC'den temin edilmiştir. RPMI 1640 (Invitrogen, A.B.D) içerisine \%10 fetal kalf serum (FCS, Invitrogen), 100 'U/mL penisilin ve $100^{\prime} \mathrm{U} / \mathrm{mL}$ streptomisin eklenerek besiyeri hazırlanmıştır ve $37^{\circ} \mathrm{C}$ sıcaklık, hava; \%95, karbon dioksit (CO2); \%5 koşullarında hücrelerin çoğalması sağlanmıştır. Hep-2 hücre hatları içinde eşit sayıda hücre olacak şekilde 3 ayrı flaska ayrılmıştır. Desitabinden birinci flaska $1 \mu \mathrm{M}$, ikinci flaska $10 \mu \mathrm{M}$ eklenmiştir. Desitabin eklenmeyen 3. flask ise kontrol grubu olarak kullanılmıştır. Desitabin eklendikten 24 saat sonra hücrelerin medyumları değiştirilmiş olup birinci ve ikinci flaska tekrardan $1 \mu \mathrm{M}$ ve $10 \mu \mathrm{M}$ desitabin eklenmiştir. Bu şekilde 72 saat süresince her 24 saat sonunda bu işleme aynı şekilde devam edilmiştir.

\subsection{Klasik Sitogenetik Yöntem ile Hep-2 Hücrelerinden Kromozom Elde Etme}

72 saat sonunda her 3 flasktaki Hep-2 hücreleri santrifüj sonrasında 15 ml' lik falkon tüplere alınmış ve üzerlerine RPMI 1640 Medium (Biological Industries, BİO1-106-1B ) eklenmiştir. Sonrasında harvest işlemine geçilmiştir.

\subsubsection{Harvest}

Hep-2 hücrelerinin bulunduğu her bir tüpe $0.2 \mu \mathrm{g} / \mathrm{ml}$ kolsemid damlatımış ve tüpler 1 saat etüvde bekletilmiştir. Daha sonra örnekler 3000 rpm'de 5 dk santrifüj edilmiştir. Santrifüj sonrasında süpernatant atılarak \% $0.75 \mathrm{M}$ KCL solüsyonundan her bir tüpe $5 \mathrm{ml}$ eklenmiştir ve örnekler $10 \mathrm{dk}$ oda sıcaklığında bekletilmiştir. Sonrasında tekrar 3000 rpm'de 5 dk santrifüj işlemi yapılmıştır. Süpernatant atılmış ve vorteks üzerinde tüplere fiksatif (3:1 metanol-asetik asit karışımı) solüsyonundan eklenmiştir.

\subsubsection{Yayma}

Harvest işleminden sonra örnekler $3000 \mathrm{rpm}$ 'de $5 \mathrm{dk}$ santrifüj edilmiştir. Süpernatant atılmış ve taze fiksatif örneklere eklenmiştir. Santrifüj işlemi iki kez daha tekrarlanmıştır. Sonrasında süpernatant atılmış ve tüplere 1,5 ml fiksatif eklenmiştir. Yayma yaparken lamların yayma yapılacak yüzü 3-4 sn çeşme suyuna tutulup hemen sonrasında temiz pipet kullanılarak alınan örnekler lamın farklı bölgelerine bir damla olacak şekilde 4 damla damlatılmıştır. Daha sonra lamlara eskitme (yaşlandırma) işlemi uygulanmıştır (110 derece sıcaklıkta 25 dakika).

\subsubsection{Bantlama}

Lamlar Tripsin+PBS solüsyonunun olduğu şalede $15 \mathrm{sn}$ bekletilmiş daha sonra tripsin enziminin etkisinin giderilmesi için sadece PBS içeren şaleye daldırılıp çıkarılmıştır. Ardından lamlar 2 dk boyada (Leishman) bekletilmiştir. Son olarak disitile suyun olduğu şaleye batırılıp çıkarılan lamlar kromozom analizi için hazır hale getirilmitir.

\subsubsection{Kromozom Analizi}

Bantlama sonrasında Hep-2 hücre kromozomlarını içeren lamlar 1şık mikroskobu altında analiz edilmiştir. Her 3 gruptan 100' er metafaz plağı sayılmış ve 20’ şer karyotip yapılmıştır. Kromozom analizi ISCN (An International System for Human Cytogenetic Nomenclature)'ün belirlediği kurallar dikkate alınarak yapılmıştır. 


\section{Bulgular}

Hep-2 hücrelerinden yapılan kromozom analizinde Desitabinsiz, $1 \mu \mathrm{M}$ ve $10 \mu \mathrm{M}$ Desitabin içeren üç grubun herbirinden 100 metafaz görüntüsü incelenmiş ve bu metafazlardan 20'şer tane karyotip yapılmıştır. Tablo 1 de her üç grupta incelen kromozomların sayısal ve yapısal olarak genel bir karşılaştırılması yer almaktadır. Desitabinsiz Hep-2 hücre grubundan elde edilen kromozomlar ile $1 \mu \mathrm{M}$ Desitabin içeren Hep-2 hücre grubundan elde edilen kromzomların sayısal değerlendirmesi arasında istatistiki olarak anlamlı bir değişim olup olmadığı Fisher exact testi ile araştırılmış ancak iki grup arasında anlamlı bir değişimin olmadığı anlaşılmıştır $(\mathrm{P}>0,05)$. Aynı şekilde Desitabinsiz grup ile $10 \mu \mathrm{M}$ Desitabin içeren grup arasında da yine anlamlı bir değişim tespit edilememiştir $(\mathrm{P}>0,05)$. Desitabinsiz Hep-2 hücre kromozomlarındaki yapısal farklılıklar ile Desitabin içeren iki grup arasındaki farklılıkların da istatistiki olarak anlamlı olmadığı görülmüştür $(\mathrm{P}>0,05)$.

Table 1. Desitabinsiz, $1 \mu \mathrm{M}$ ve $10 \mu \mathrm{M}$ Desitabin içeren Hep-2 hücrelerinin kromozom analizinin genel değerlendirilmesi

\begin{tabular}{|c|c|c|c|c|c|c|c|c|c|}
\hline & & & \multicolumn{5}{|c|}{ Kromozom Sayısı } & & \\
\hline $\begin{array}{l}\text { Desitabin } \\
\text { Miktarı }\end{array}$ & İ.H. & K.S. & 76 & 75 & 74 & $<74$ & $76>$ & $\begin{array}{l}\text { Y. } \\
\text { K. } \\
\text { A. } \\
\text { O. }\end{array}$ & $\begin{array}{l}\text { T. } \\
\text { Y. } \\
\text { K. } \\
\text { A. }\end{array}$ \\
\hline Desitabinsiz & 100 & 20 & 42 & 23 & 19 & 4 & 12 & 32 & 17 \\
\hline $\begin{array}{l}1 \mu \mathrm{M} \\
\text { Desitabin }\end{array}$ & 100 & 20 & 44 & 26 & 17 & 3 & 10 & 31 & 18 \\
\hline $\begin{array}{l}10 \mu \mathrm{M} \\
\text { Desitabin }\end{array}$ & 100 & 20 & 41 & 27 & 16 & 5 & 11 & 34 & 16 \\
\hline
\end{tabular}

Tablo 1.'deki Kısaltmalar: I.H.: Incelenen Hücre Saylsı, K.S.: Karyotip Saylsı, Y.K.A.O.: Yapısal Kromozom Anomalisinin Ortalamasl, T.Y.K.A.O: Tekrarlayan Yapısal Kromozom Anomalisinin Ortalamast

Şekil 1 ve Şekil 2' de her 3 grupta tespit edilen metafaz görüntüleri ve karyotip görüntüleri yer almaktadır. Her 3 gruptan elde edilen metafazların tamamında çok sayıda kromozom anomalisinin olduğu görülmüştür. Birçok kromozom anomalisinin tekrarlamayan (non-recurrent) kromozom anomalilerinden oluştuğu diğer anomalilerin ise en az iki metafaz plağında tekrarlayan (recurrent) nitelikte olduğu tespit edilmiştir. Tekrarlayan bazı kromozom anomalileri D, D1, M1, M2 gibi kısaltmalar ile işaretlenmiş ve bu işaretlerin anlamları Tablo 2'de açıklanmıştır. M1 markır kromozomunun bütün metafazlarda yer aldığ görülmüştür. M2 ve 12. kromozomun derivatif formları olduğunu düşündüğümüz (D12a, D12b, D12c) kromozom anomalilerinin de Hep-2 hücrelerinde oldukça sık tekrarlayan anomaliler olduğu belirlenmiştir. del(6q) yani 6. kromozomun q kolunun farklı bölgelerinden delesyona uğradığı (Dl 6a ve D1 6b) anormal kromozomların da çok sayıda metafazda yer aldığı tespit edilmiştir. Derivatif X kromozomunun (der $(\mathrm{X}))$ ise nispeten daha az siklıkta tekrarlayan kromozomlardan birisi olduğu belirlenmiştir. 


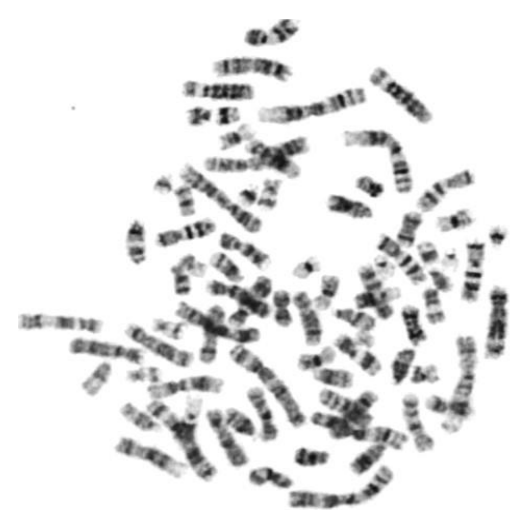

a. Desitabinsiz Kültür (76 kromozom)

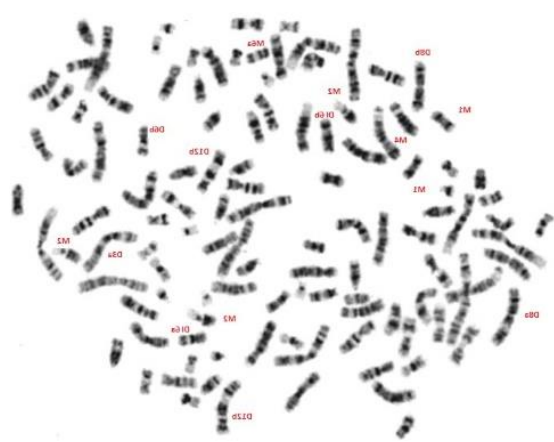

c. Desitabinsiz Kültür (115 kromozom)

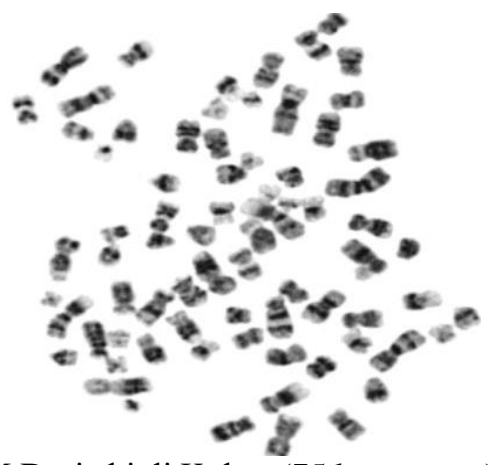

e. $1 \mu \mathrm{M}$ Desitabinli Kültür (75 kromozom)

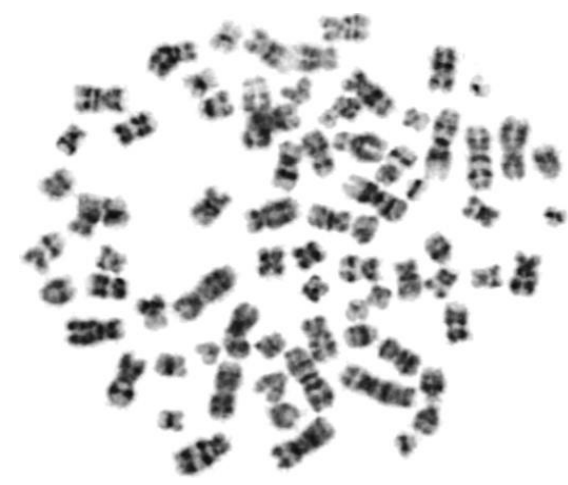

b. Desitabinsiz Kültür (75 kromozom)

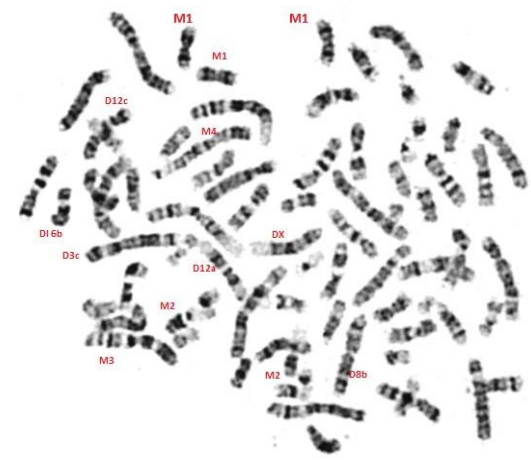

d. $1 \mu \mathrm{M}$ Desitabinli Kültür (73 kromozom)

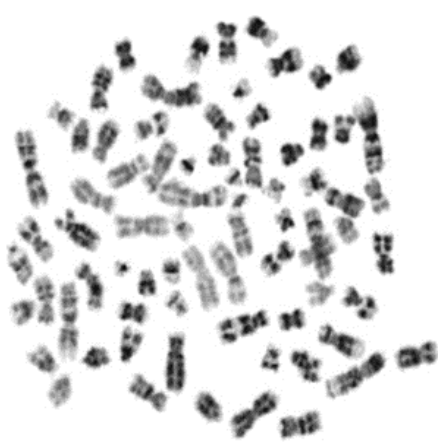

f. $10 \mu \mathrm{M}$ Desitabinli Kültür (72 kromozom)

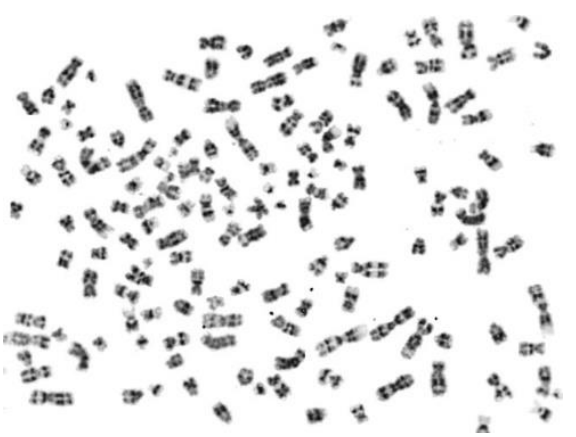

g. $10 \mu \mathrm{M}$ Desitabinli Kültür (184 kromozom)

Şekil 1. (a-d) Desitabinsiz ve $1 \mu \mathrm{M}$ Desitabin içeren Hep-2 hücrelerine ait metafaz kromozomları (e-g) $1 \mu \mathrm{M}$ ve $10 \mu \mathrm{M}$ Desitabin içeren Hep-2 hücrelerine ait metafaz kromozomları 


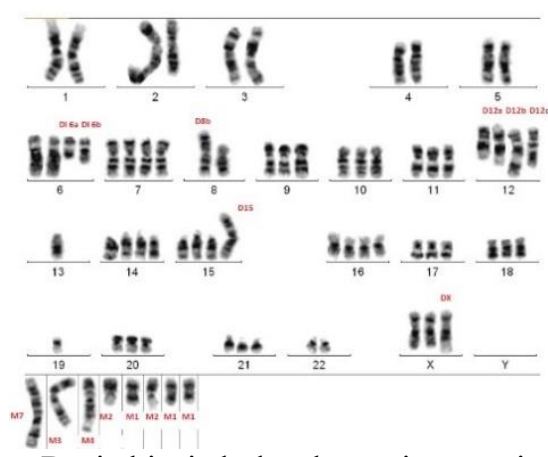

a. Desitabinsiz kültür karyotip örneği

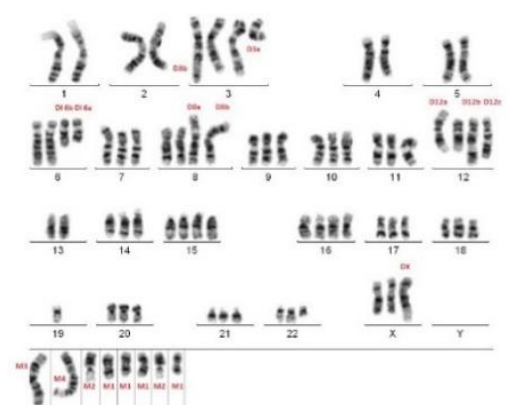

c. $1 \mu \mathrm{M}$ Desitabinli kültür karyotip örneği

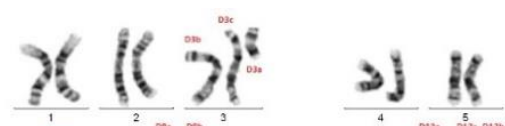

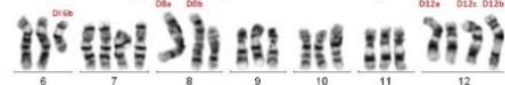
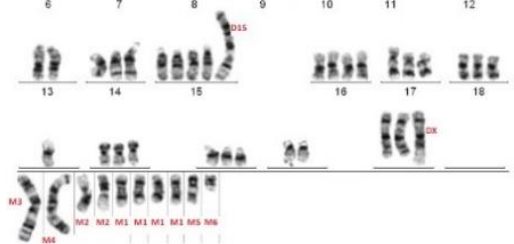

b. Desitabinsiz kültür karyotip örneği

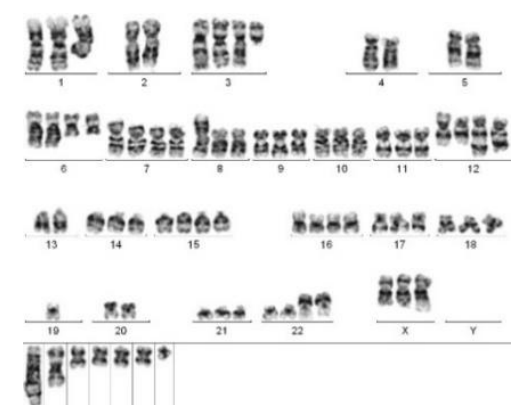

d. $1 \mu \mathrm{M}$ Desitabinli kültür karyotip örneği

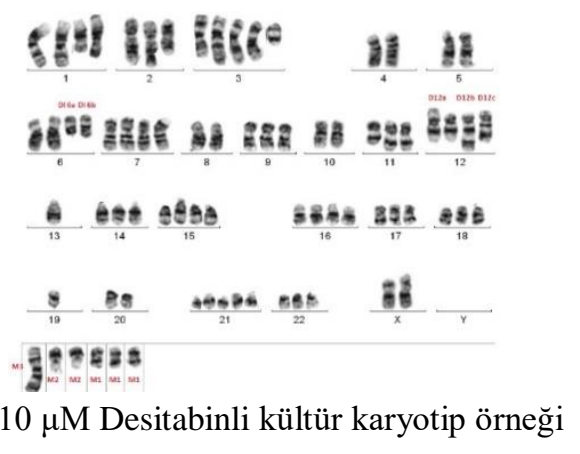

Şekil 2. (a-e) Desitabinsiz, $1 \mu \mathrm{M}$ ve $10 \mu \mathrm{M}$ Desitabin içeren Hep-2 hücrelerine ait karyotip görüntüleri 
Tablo 2. Desitabinsiz, $1 \mu \mathrm{M}$ ve $10 \mu \mathrm{M}$ Desitabinli kültür Hep-2 hücre hatlarının kromozom analizinde her üç grupta da ortak olarak tekrarlayan kromozom anomalileri

\begin{tabular}{|l|l|}
\hline Kisaltmalar & \multicolumn{1}{|c}{ Açıklamalar } \\
\hline M1 & $\begin{array}{l}\text { Birçok karyotipte yer alan markır kromozomlarından birincisi. Bu markır } \\
\text { kromozomu literatürde bildirilen Hep-2 hücre hatlarında da gösterilmiştir (Wang ve } \\
\text { ark, 2015)' de 'Y' kromozomu olduğu düşünülen ve (Chen ve ark., 1988)'de markır } \\
\text { kromozom olarak değerlendirilip '7' ile numaralandırılan kromozom. Kesin } \\
\text { olmamakla birlikte bu markır kromozomunun idic (5p) olabileceğini } \\
\text { düşünmekteyiz. }\end{array}$ \\
\hline M2 & $\begin{array}{l}\text { Karyotiplerde yer alan markır kromozomlarından ikincisi. Bu markır kromozomu } \\
\text { literatürde daha önce Hep-2 hücre hatlarından yapılan kromozom analizinde de } \\
\text { gösterilmiştir. (Chen ve ark, 1988)'de derivatif 13 olarak gösterilen ve '16' diye } \\
\text { numaralandırılan kromozom. }\end{array}$
\end{tabular}

M3 Karyotipte yer alan markır kromozomlarından üçüncüsü. Bu markır kromozomu literatürde daha önce Hep-2 hücre hatlarından yapılan kromozom analizinde de gösterilmiştir (Wang ve ark, 2015)' de 'M' olarak adlandırılmıştır).

M4 Markır olarak adlandırdığımız kromozomlardan dördüncüsü. Kesin olmamakla birlikte bu markır kromozomunun 1. kromozomdan köken alan derivatif kromozom olabileceğini düşünmekteyiz.

\begin{tabular}{l|l} 
M5 & $\begin{array}{l}\text { Markır olarak adlandırdığımız kromozomlardan beşincisi. } \\
\text { M6 }\end{array}$ \\
\hline Markır olarak adlandırdığımız kromozomlardan altıncısı. \\
\hline D3a & $\begin{array}{l}\text { Markır olarak adlandırdığımız kromozomlardan yedincisi. } \\
\text { Derivatif 3. Bu markır kromozomu literatürde daha önce Hep-2 hücre hatlarından } \\
\text { numaralandırılmıştır. }\end{array}$
\end{tabular}

\begin{tabular}{|c|c|}
\hline D3b & Derivatif 3. kromozomlardan birisi \\
\hline D3c & Bir başka derivatif 3 \\
\hline Dl 6a & $\begin{array}{l}\text { Sitogenetik incelemede tespit edilen, } 6 \text {. kromozomun q kolunun delesyona uğradığ } \\
\text { anormal kromozomlardan birisi. Bu del (6q) kromozomu literatürde daha önce Hep- } \\
2 \text { hücre hatlarından yapılan karyotip analizinde de gösterilmiştir (Chen ve ark., } \\
1988) \text { 'de '36' olarak simgelendirilmiştir. }\end{array}$ \\
\hline Dl $6 b$ & $\begin{array}{l}\text { Sitogenetik incelemede tespit edilen, } 6 \text {. kromozomun q kolunun delesyona uğradığ } 1 \\
\text { anormal kromozomlardan birisi. }\end{array}$ \\
\hline D8a & Derivatif 8 . kromozomlardan birisi \\
\hline D8b & $\begin{array}{l}\text { Bir diğer derivatif } 8 \text {. Bu derivatif kromozom literatürde daha önce Hep-2 hücre } \\
\text { hatlarından yapılan karyotip analizinde de gösterilmiştir (Chen ve ark, 1988)'de } \\
\text { ' } 37 \text { ' olarak simgelendirilmiştir. }\end{array}$ \\
\hline D12a & Derivatif 12 \\
\hline D12b & Bir başka derivatif 12 \\
\hline D12c & $\begin{array}{l}\text { 12. kromozomun bu derivatif formu daha önceki Hep-2 hücre hatlarından yapılan } \\
\text { sitogenetik incelemelerde de gösterilmiştir (Chen ve ark, 1988)'de '15' şeklinde } \\
\text { simgelendirilmiştir). }\end{array}$ \\
\hline D15 & $\begin{array}{l}\text { Derivatif } 15 . \mathrm{Bu} \text { anormal kromozom daha önceki Hep- } 2 \text { hücre hatlarından yapılan } \\
\text { sitogenetik incelemelerde de gösterilmiştir (Chen ve ark., 1988)'de '17' şeklinde } \\
\text { simgelendirilmiştir). }\end{array}$ \\
\hline DX & Derivatif $\mathrm{X}$ \\
\hline
\end{tabular}




\section{Tartışma ve Sonuç}

Hücre hatları ile ilgili çalışma yapılırken üzerinde durulması gereken hususlardan birisi hücre hatlarının diğer hücre hatları ile ve mikoplazma ile kontamine olma riskidir. Hücre hatlarında tür içi hatta türler arasında çapraz kontaminasyonun olabildiği ilk olarak Stan Gartler tarafından 1966 yılında gösterilmiştir. Sonrasında 1970'lerin başında Walter Nelson-Rees tarafından bu durum teyit edilmiştir. İlgili bilim insanları o dönemde çok büyük orandaki hücre hattının kontamine olduğunu ve bu kontamine hücrelerin hücre hattı bankaları tarafından dünya genelindeki laboratuvarlara dağıtıldığını göstermişlerdir (Nelson ve ark, 1981). Aradan uzunca bir süre geçmiş olmasına rağmen çapraz kontaminasyon ve yanlış etiketleme ile ilgili sorun bugün için de geçerlidir (Kaur ve ark, 2012). Bu bakımdan hücre hatlarıyla çalışma yapılacaksa, öncelikle çalışma yapılacak hücre hattının tür içi mi yoksa tür dışı mı veya çalışılmak istenilen hastalıkla ilgili mi yoksa farklı hastalıklarla ilgili mi sorularına yanıt arayarak çalışmaya başlanmalıdır. Bu bağlamda hücre hatlarının kökeninin aydınlatılması için bildirilen çeşitli yöntemler vardır. $\mathrm{Bu}$ yöntemler arasında karyotip analizi, immünolojik farklılıklara bağlı ayrıştırma çalışmaları ve short tandem repeat (STR) profilleme çalışması sayılabilir (Almeida ve ark, 2016).

Hep-2 hücre hattı uzun yıllar önce Hela hücreleri ile kontamine olmuş bir larenks kanseri (LKa) hücre hattıdır. Günümüzde ATCC' den veya başka hücre hattı bankalarından satın alınarak laboratuvarlarda kullanılan Hep-2 hücre hatları aslında saf LKa hücre hatları olmayıp Hela hücreleri ile kontamine olmuş hücre hatlarıdır (www.lgcstandards-atcc.org). Hep-2 Hücre hatlarının kromozom yapısına ait ilk bilgiler 1963 yılında Norryd C ve ark tarafından yapılan karyotip analizi ile ortaya çıkarılmıştır (Norryd ve ark, 1963). İlgili çalışmada 600 metafaz sayılmış ve 6 tane karyotip yapılmıştır. Yapılan karyotip analizi, henüz o yıllarda bantlama tekniklerinin geliştirilmemiş olmasından dolayı, kromozomların boylarına göre yapılmıştır. Sayısal değerlendirmede hücrelerin 69-81 arasında değişmekle birlikte daha çok 77 kromozom içerdiği bildirilmiştir. Buna ek olarak 131-156 arasında değişen kromozom sayısına sahip hücrelerin de görüldüğü vurgulanmıştır. İlgili çalışmanın karyotip görüntüsü ile bizim çalışmanın karyotip görüntülerini karşılaştırdığımızda, yapısal kromozom değişiminin bizim çalışmamızda daha fazla olduğunu ve markır kromozomların yine bizim çalışmamızda daha bol görüldüğünü söyleyebiliriz. Hücre hatları oluşturulurken uygulanan genetik manipulasyon hücrelerin fenotip olarak daha farklı olmasına yol açabilmekte ve hücrelerin asıl fonksiyonlarında çeşitli değişiklikler oluşturabilmektedir. Hücre seri pasajlarıyla birlikte oluşan genotipik ve fenotipik farklılıklar hücre hattında ciddi heterojeniteye sebeb olabilmektedir. Seri pasajların yapıldığı uzun süreç içerisinde çok sayıda bölünme geçiren hücre hattına ait hücrelerde, elde edildikleri doku ve hastalık ile ilişkisiz, bolca genomik hatalar oluşabilmektedir. Bu yüzden çalışma sonuçları yorumlanırken bu durum mutlaka göz önünde bulundurulmalıdır (Kaur ve ark, 2012).

LKa baş-boyun bölgesinde en sık görülen kanserdir (Saito ve ark, 2013) ve kötü huylu tümörlerin \% 23'ünü oluşturur (Charles ve ark, 1999). Kanser gelişiminde en önemli risk faktörlerinin sigara ve alkol alışkanlığının olduğu bildirilmektedir (Manjarrez ve ark, 2006). LKa genel olarak erkeklerde en sık görülen kanserlerden biridir. Son yıllarda cerrahi ve radyoterapi yöntemlerindeki gelişmelere rağmen LKa'nın tedavisi konusunda istenilen başarı elde edilememiştir. LKa'nın erken tanısı ve tedavisi için yeni yöntemlere ihtiyaç vardır (Saito ve ark, 2013). LKa hücre hattı olan Hep-2 hücrelerinin her ne kadar Hela hücreleri ile kontamine olduğu kesinleşmiş olsa da, Hep-2 hücre hatt1 LKa' nın oluşum ve gelişim süreçlerinin araştırılması, tanı ve tedavide umut ışığı olabilicek biyobelirteçlerin ortaya çıkarılması için sıkça kullanılmaktadır (Dellavance A,2019). Örneğin LKa' lı hastalara ait kanserli dokularda ekspresyon seviyesi anlamlı şekilde değişen mikroRNA (miRNA)' ların Hep-2 hücre hatları üzerinde fonksiyonel çalışmaları yapılmış ve birçok tümörsüpresör miRNA veya onkogenik miRNA tespit edilmiştir (Karataş ve ark, 2016; Karataş, 2018).

Kanser hücre hatları kullanılarak yapılan araştırmalarda, hücrelere uygulanan çeşitli moleküllerin, ilaçların veya diğer maddelerin genomda oluşturdukları değişikliklerle hücre proliferasyonuna, invazyonuna ve migrasyonuna yaptıkları katkı ortaya çıkarılabilmektedir. Kanser hücre davranışında meydana gelen bu değişimlerde kromozom anomalilerindeki farklılığın katkısının ne olduğunun gösterilmesi tümör yapısının daha iyi aydınlatılması için önemli olduğu değerlendirilmektedir (Kasai ve ark, 2018).

LKa kanser hastalarının doku hücrelerinden yapılan kromozom analizinde LKa' lı birçok hastanın oldukça kompleks karyotip özelliğine sahip olduğu bildirilmiştir (Jin ve ark, 2002). Çalışmamızın sonuçlarında da görüleceği üzere Hep-2 hücrelerinin tamamı oldukça kompleks karyotip özelliği sergilemektedir. Bu durum Hep-2 hücrelerinin benzer genomik yapıya sahip olmayıp oldukça heterojen 
özellik sergilediğinin göstergesi olarak değerlendirilebilir. Aslında Hep-2 hücre hattı gibi birçok hücre hattı da heterojen hücre popülasyonlarını bir arada barındırmaktadır. Bu bakımdan kanserlerde genomik değişiklikleri ortaya çıkaran moleküler yöntemler ile karyotip analiz sonuçlarının birlikte değerlendirilmesi, tümör genomunun daha iyi anlaşılması açısından önemlidir (Kasai ve ark, 2018).

Tüm bunlara rağmen hücre hatları ile yapılan moleküler çalışmaların birçoğunda karyotip analizi yapılamamaktadır. Bu durumun çeşitli sebepleri vardır; Hücre hatlarından kromozom elde etmenin nispeten zor olması, kromozom morfolojisinin kötü olması, kompleks kromozomal değişimi içeren çok sayıda kromozomun bulunması gibi sebepler çalş̧malarda karyotip analizine duyulan isteği azaltmaktadır (Joos ve ark, 2003). Literatürde Hep-2 hücre hattı kromozomlarının analiz edildiği çalışma sayısı oldukça sınırlıdır. Üstelik Hep-2 kromozomlarının gösterildiği çalışmaların bir kısmında elde edilen kromozom kalitesi, yapılacak yeni araştırmalara yardımcı olacak kalitede değildir. Aynı zamanda ilgili yayınlarda ya hic karyotip görüntüsünün olmaması (Draganov ve ark, 2010) ya da bir kaç tane bulunması (Chen ve ark, 1988) çok sayıdaki hem sayısal hem de yapısal kromozom anomalisininin literatür ile karşılaştırılmasını sınırlandırmaktadır. Bu nedenlerden dolayı çalışma sonuçlarımızın Hep-2 hücre hattından kromozom analizi elde etmeyi planlayan araştırmacılara yardımcı olabileceğini düşünüyoruz.

Desitabinin $1 \mu \mathrm{M}$ ve $10 \mu \mathrm{M}$ dozunun ve 72 saatlik hücre kültür süresinin hipometilasyon için yeterli doz ve süre olduğu ile ilgili çok sayıda çalışma bulunmaktadır (Hagemann ve ark, 2011; Zych ve ark, 2013). Çalışmamızda Desitabinsiz Hep-2 hücre kromozomları ile $1 \mu \mathrm{M}$ ve $10 \mu \mathrm{M}$ Desitabin içeren gruptakiler karşılaştırılmış ancak gerek sayısal gerekse yapısal kromozom değişimleri açısından istatistiki olarak anlamlı bir sonuç elde edilememiștir. Bu durum çalışmamızda uygulanan Desitabin dozu ve ve kültür süresi ile hücrelerde oluşan hipometilasyonun Hep-2 hücrelerinde kromozomal farklılık oluşturmadığının kanıtı olarak değerlendirilebilir. Çalışmamızda uyguladığımız Desitabin dozunun ve kültür süresinin artırılmasıyla hücrelerde oluşacak hipometilasyonun kromozomal düzeyde etkisini gösterebileceğini düşünüyoruz.

\section{Kaynaklar}

Almeida JL, Cole KD, Plant AL. (2016). Standards for Cell Line Authentication and Beyond. PLoS Biology, 14(6):e1002476.

Ando T, M Nishimura and Y Oka. (2000). Decitabine (5-aza-2'-deoxycytidine) decreased DNA methylation and expression of MDR-1 gene in K562/ADM cells. Leukemia,14, 1915-1920

Chen T.R. , Re-evaluation of HeLa, HeLa S3, and HEp-2 karyotypes Cytogenet Cell Genet 1988;48:19-24

Christman JK. (2002). 5-Azacytidine and 5-aza-2 -deoxycytidine as inhibitors of DNA methylation: mechanistic studies and their implications for cancer therapy. Oncogene, 21:5483-5495.

Dellavance A, Andrade LEC. (2019). Detection of Autoantibodies by Indirect Immunofluorescence Cytochemistry on Hep-2 Cells. Methods Mol Biol.,1901:19-46.

Draganov M, G. Miloshev, N. Popov, M. Murdjeva, D. Staneva, M. Kostova, D. Draganov \& N. Tomlekova. (2010). Molecular and Cytogenetic Criteria for Identification of Serum-Free Cell Cultures, Biotechnology \& Biotechnological Equipment, 24:sup1, 139-143

Hagemann S, Heil O, Lyko F, Brueckner B. (2011). Azacytidine and Decitabine Induce Gene-Specific and Non-Random DNA Demethylation in Human Cancer Cell Lines. Campbell M, ed. PLoS $O N E ., 6(3): \mathrm{e} 17388$.

Hagemann S, Heil O, Lyko F, Brueckner B. (2011). Azacytidine and decitabine induce gene-specific and non-random DNA demethylation in human cancer cell lines. PLoS One., 7;6(3):e17388.

Harrison JJ, Anisowicz A, Gadi IK, Raffeld M, Sager R. (1983). Azacytidine-induced tumorigenesis of CHEF/18 cells: correlated DNA methylation and chromosome changes. Proc Natl Acad Sci., 80(21):6606-10. 
https://www.lgcstandards-atcc.org/products/all/CCL-23.aspx?geo_country=tr\#generalinformation (E.T.: 15.03.2019)

https://www.lgcstandardsatcc.org/Products/Cells_and_Microorganisms/Cell_Lines.aspx?geo_country=tr 15.03.2019)

Jin C, Jin Y, Wennerberg J, Akervall J, Dictor M, Mertens F. (2002). Karyotypic heterogeneity and clonal evolution in squamous cell carcinomas of the head and neck. Cancer Genet Cytogenet., 5;132(2):85-96.

Joos S, Granzow M, Holtgreve-Grez H, Siebert R, Harder L, Martín-Subero JI, Wolf J, Adamowicz M, Barth TF, Lichter P, Jauch A. (2003). Hodgkin's lymphoma cell lines are characterized by frequent aberrations on chromosomes $2 \mathrm{p}$ and $9 \mathrm{p}$ including REL and JAK2. Int $J$ Cancer., 10;103(4):489-95.

Karatas OF, Suer I, Yuceturk B, Yilmaz M, Hajiyev Y, Creighton CJ, Ittmann M, Ozen M. (2016). The role of miR-145 in stem cell characteristics of human laryngeal squamous cell carcinoma Hep-2 cells. Tumour Biol. ;37(3):4183-92.

Karatas OF. (2018). Antiproliferative potential of miR-33a in laryngeal cancer Hep-2 cells via targeting PIM1. Head Neck., 40(11):2455-2461.

Kasai F, Hirayama N, Ozawa M, Satoh M, Kohara A. (2018). HuH-7 reference genome profile: complex karyotype composed of massive loss of heterozygosity. Hum Cell., 31(3):261-267.

Kaur G, Dufour JM. (2012). Cell lines: Valuable tools or useless artifacts. Spermatogenesis., 2(1):15.

Lee Y, Kim YJ, Choi YJ, Lee JW, Lee S, Cho YH, Chung HW. (2015). Radiation-induced changes in DNA methylation and their relationship to chromosome aberrations in nuclear power plant workers. Int J Radiat Biol., 91(2):142-9.

Lucey BP, Nelson-Rees WA, Hutchins GM. (2009). Henrietta Lacks, HeLa cells, and cell culture contamination. Arch Pathol Lab Med., 133(9):1463-7.

Maqsood MI, Matin MM, Bahrami AR, Ghasroldasht MM. (2013). Immortality of cell lines: challenges and advantages of establishment. Cell Biol Int., 37(10):1038-45.

Nelson-Rees WA, Daniels DW, Flandermeyer RR. (1981). Cross-contamination of cells in culture. Science.;212:446-52.

Norryd C, Fjelde A. (1963). The chromosomes in the human cancer cell tissue culture line H. Ep.2. Cancer Res., 23:197-200.

Stresemann C, Lyko F. (2008). Modes of action of the DNA methyltransferase inhibitors azacytidine and decitabine. Int $J$ Cancer, 123:8-13.

Wang M, Wu C-P, Pan J-Y, Zheng W-W, Cao X-J, Fan G-K. (2015). Cancer-Associated Fibroblasts in a Human HEp-2 Established Laryngeal Xenografted Tumor Are Not Derived from Cancer Cells through Epithelial-Mesenchymal Transition, Phenotypically Activated but Karyotypically Normal. Cao J, ed. PLoS ONE.,10(2):e0117405.

Zych J, Stimamiglio MA, Senegaglia AC, et al. (2013). The epigenetic modifiers 5-aza-2'deoxycytidine and trichostatin A influence adipocyte differentiation in human mesenchymal stem cells. Braz J Med Biol Res., 46(5):405-16. 